\title{
“Gadget Freak (Smartphone)" Animasi Motion Graphic Iklan Layanan Masyarakat
}

\author{
Kristyannanda Aprilia Putra ${ }^{1}$, Mahendradewa Suminto ${ }^{2}$, Pandan Pareanom Purwacandra ${ }^{3}$ \\ Program Studi Animasi, Fakultas Seni Media Rekam, \\ Institut Seni Indonesia Yogyakarta \\ e-mail: kristyannandaap@gmail.com ${ }^{1}$,mahendrads@isi.ac.id ${ }^{2}$, \\ pandan@isi.ac.id ${ }^{3}$,
}

\begin{abstract}
Abstrak
Melihat banyaknya pengguna smartphone dan menjadikan generasi anak muda sekarang menjadi generasi individualis, menjadikan ide pada film animasi 'Smartphone Addiction' yang menggugah keinginan untuk merubah prilaku anak muda sekarang untuk lebih bersikap bijak terhadap perkembangan teknologi lewat animasi motion graphic, yang berisi gambaran-gambara perilaku kita sekarang ini yang terlalu menjadi pecandu smartphone.

Teknik animasi motion graphic digunakan dalam penciptaan karya animasi, 'Remaja dan Smartphone' dengan alasan ingin memberikan penyajian yang sederhana dan mudah dipahami lewat style gambar flat design dan teknik animasi motion yang di padukan dengan narasi untuk memperjelah isi dan pesan pada film animasi 'Remaja dan Smartphone'.

Film animasi 'Remaja dan Smartphone' sebuah film infografis yang di dalamnya berisi kebiasaan-kebiasaan anak muda sekarang yang terlalu menjadi pecandu smartphone yang mengakibatkan masa muda mereka menjadi generasi individualis, kehidupan yang membosankan dan mereka hanya hidup di ruang lingkup dunia maya saja, di dunia nyata hanya menjadi manusia asing, sehingga mulai dari sekarang generasi anakmuda yang cerdas harus lebih bias bersikap bijak terhadap perkembangan teknologi.
\end{abstract}

Kata kunci: Smartphone, Perkembangan Teknologi, Iklan Layanan Masyarakat 


\begin{abstract}
Seeing the number of smartphone users and making the generation of young people now become an individualist generation, making the idea of an animated film 'Smartphone Addiction' that arouses the desire to change the behavior of young people now to be more wise about technological developments through animated motion graphics, which contain images of behavior we are now too much of a smartphone addict.

Motion graphic animation techniques are used in the creation of animated works, 'Teenagers and Smartphones' with the reason that they want to provide a simple and easyto-understand presentation through flat design drawing styles and motion animation techniques that are combined with narration to fill the contents and messages in the animated film' Teenagers and Smartphone'.

Animated film "Remaja dan Smartphones' an infographic film that contains the habits of young people who are now too addicted to smartphones which results in their youth becoming an individualist generation, a boring life and they only live in the scope of cyberspace, in the world the real thing is only being a foreign human, so that from now on the generation of smart youngsters must be more biased to be wise about technological developments.
\end{abstract}

Keywords: Smartphone, Technology Development, Public Service Advertising

\title{
Pendahuluan
}

Tidak dapat dipungkiri lagi bahwa sekarang teknologi telah berkembang kian pesatnya. Teknologi diciptakan untuk mempermudah urusan manusia. Berbagai macam jenis teknologi yang tidak terhitung jumlahnya dapat kita jumpai di zaman yang modern ini. Salah satu contoh teknologi yang sangat popular adalah gadget Setiap orang menggunakan gadget dengan teknologi yang modern seperti televisi, telepon genggam, laptop, komputer tablet, smart phone, dan lain-lain. Gadget ini dapat ditemui dimanapun, baik pada orang dewasa maupun anak-anak. Anak-anak kini telah menjadi konsumen aktif dimana banyak produk-produk elektronik dan gadget yang menjadikan anak-anak sebagai target pasar mereka. "Apalagi jangankan anak-anak, orang tua pun ada yang sangat menyukai gadget sampai disebut gadget freak." (Muzakki, 2013)

Panji Ismail (2013) Dari faktor semakin banyaknya teknologi yang bersaing menyebabkan harga dari gadget semakin terjangkau. Yang dulunya gadget adalah sesuatu yang elit, akan tetapi sekarang sudah tidak lagi. Dilihat dari kenyataan sekarang, sudah menjadi hal yang biasa bahwa anak-anak SD saja memiliki gadget berupa smart phone taupun Hand phone sebagai bahan mainan mereka. Dahulu orang yang mampu membeli gadget hanyalah orang golongan menengah keatas, akan tetapi 